\title{
Samoupravni preobražaj kulture kroz delegatsku prizmu: primjer Samoupravne interesne zajednice kulture općine Pula 1974. - 1990."
}

\author{
ANITA BUHIN \\ Filozofski fakultet, Sveučilište Jurja Dobrile u Puli \\ Pula, Hrvatska \\ anita.buhin@gmail.com
}

\begin{abstract}
Samoupravni preobražaj kulture kao koncept dobiva na važnosti nakon mnogobrojnih političkih i društvenih promjena u Socijalističkoj Federativnoj Republici Jugoslaviji, poput donošenja novoga Ustava 1974. i uvođenja Zakona o udruženom radu 1976. godine. Sam pojam obuhvaća raspon od partijske politike i radničkih (amaterskih) kulturnih praksi kroz slobodnu razmjenu rada do pitanja humanizacije rada, međuljudskih odnosa i kulture kao načina života. Proklamirana daljnja demokratizacija kulture trebala je biti ostvarena uspostavljanjem odnosa slobodne razmjene rada između kulturnih radnika (odnosno davatelja usluga) i radnika u organizacijama udruženog rada i građana u mjesnim zajednicama, koja se trebala odvijati u organizacijama udruženog rada i samoupravnim interesnim zajednicama. Samoupravne interesne zajednice kulture na razini općine trebale su pomoću uspostave dvodomnoga vijeća delegata (jedno sačinjeno od "korisnika”, odnosno delegata organizacija udruženog rada materijalne proizvodnje i mjesnih zajednica, a drugo od "davalaca”, odnosno delegata organizacija udruženog rada kulture, amaterskih kulturno-umjetničkih društava i samostalnih umjetnika) omogućiti zadovoljavanje posebnih i općih potreba u kulturi svih stanovnika općine. Na primjeru općine Pula ovaj rad analizira uspješnost kulturne reforme na mikrorazini, stavljajući poseban fokus na funkcioniranje delegatskoga sustava.
\end{abstract}

Ključne riječi: kultura; samoupravljanje; socijalizam; Savez komunista Jugoslavije; Pula

\section{Uvod}

Pitanje socijalističkoga preobražaja kulture nalazilo se u temeljima marksističkoga, pa tako i jugoslavenskoga ideološkog promišljanja. I dok su prve godine jugoslavenskoga socijalističkog društva obilježile agitpropovske

* Ovaj je rad financirala Hrvatska zaklada za znanost projektom HRZZIP-01-2018-5394 (Mikrostrukture jugoslavenskoga socijalizma: Hrvatska 1970-1990). 
kulturne aktivnosti, sredinom 50-ih jugoslavenski (kulturno-)ideološki teoretičari počeli su kreirati specifičnu jugoslavensku kulturnu politiku, temeljenu na klasičnim marksističko-lenjinističkim tekstovima i ideji samoupravljanja, koja je ubrzo postala temeljem jugoslavenske socijalističke ideologije. Stoga je i sam koncept „socijalističke kulture” slijedio teorijske razrade jugoslavenskoga samoupravnog socijalizma te političke, društvene i strukturne promjene u jugoslavenskome društvu tijekom kasnijih desetljeća, pogotovo 60-ih i 70-ih, kad su donesena dva Ustava (1963. i 1974.) i Zakon o udruženom radu (1976.), koji će uvelike promijeniti i društveno i kulturno polje.

Međutim, za razliku od prva dva i pol desetljeća postojanja socijalističke Jugoslavije, ${ }^{1}$ kulturna politika u teoriji i praksi 70 -ih i 80 -ih u suvremenoj je historiografiji praktički potpuno zanemarena i neistražena. Tako se kulturna povijest kasnoga socijalizma u Jugoslaviji često svodi na proučavanje supkulturnih i kontrakulturnih pokreta ili prigodnih monografija različitih kulturnih institucija, a uloga kulturnih institucija i same kulturne politike često se zanemaruje. ${ }^{2} S$ druge je pak strane impresivna količina teorijskih i programskih tekstova izašlih u tome razdoblju ispod pera jugoslavenskih kulturnih ideologa i sindikalnih radnika predvođenih Stipom Šuvarom. ${ }^{3}$ Stoga se otvara potreba istraživanja radničkoga sudjelovanja u kulturi, i u kreiranju i provođenju politike i u samoj konzumaciji, odnosno sudjelovanju u kulturi, pogotovo s obzirom na društveno-političke promjene u jugoslavenskom socijalističkom društvu toga vremena.

S obzirom na obujam građe, polja istraživanja samoupravnoga preobražaja kulture su nebrojena. Osim samih teorijskih i ideoloških, političkih i društvenih procesa koji se odvijaju na kulturnom polju, pitanje uloge radnika u kulturi postaje sve važnije. Ali čak i odgovor na to pitanje ne može biti jednoznačan s obzirom na sve aspekte koje pojam kultura u socijalizmu otvara. Stoga je ovaj rad samo jedan od pokušaja raščlanjivanja samoupravljanja u kulturi kroz prizmu uspostave delegatskoga sustava u samoupravnim interesnim zajednicama (SIZ) kulture. Na primjeru jedne mikrolokacije - općine Pula - odgovorit ćemo na pitanje funkcionalnosti delegatskoga sustava kao koraka prema proklamiranoj daljnjoj demokratizaciji kulture, tj. konačnoga prepuštanja stvaranja lokalne kulturne politike radnicima i građanima. Pri-

1 Vidi: DIMIĆ, Agitprop kultura; DOKNIĆ, Kulturna politika Jugoslavije 1946-1963; VUČETIĆ, Monopol na istinu. Ovdje se mogu uključiti i radovi na temu popularne kulture i povijesti medija, pa lista za prethodno razdoblje postaje još dužom: VUČETIĆ, Koka-kola socijalizam; ROLANDI, Con ventiquattromila baci; DIMITRIJEVIĆ, Potrošeni socijalizam; NAJBAR-AGIČIĆ, Kultura, znanost, ideologija.

2 Vidi: NIKOLIĆ, CVETKOVIĆ, TRIPKOVIĆ, Bela knjiga - 1984; SENJKOVIĆ, Izgubljeno u prijenosu; SPASKOVSKA, The Last Yugoslav Generation; ZUBAK, The Yugoslav Youth Press (1968-1980).

3 Vidi npr.: GRBAC, Kultura na društvenoj pozornici; MAJER, Kultura između države i tržišta; MAJSTOROVIĆ, Kultura i demokratija; MARTINIĆ, Kultura kao samoodređenje; PRNJAT, Kulturna politika i kulturni razvoj; RANKOVIĆ, Kultura i nekultura; ŠUVAR, Politika i kultura; ŠUVAR, Kulturna politika i idejna borba; ŠUVAR, Svijet obmana. 
tom su se korisnima pokazale razne publikacije iz proučavanoga razdoblja koje su se bavile različitim aspektima kulture i radništva, časopisi i bilteni poput Kulturnoga radnika i Biltena Republičke samoupravne interesne zajednice kulture, te arhivski izvori iz Arhiva Jugoslavije i Hrvatskoga državnog arhiva. Arhiv SIZ-a kulture općine Pula, pohranjen u Pismohrani u Puli u sklopu Državnoga arhiva u Pazinu, najvećim dijelom nije sačuvan te su dostupne samo osobne datoteke i financijska izvješća. Stoga se Kulturni vjesnik, bilten SIZ-a kulture općine Pula, pokazao kao najvažniji primarni izvor, ne samo zato što zamjenjuje i donosi podatke nestale u arhivima, nego zato što i po prirodi publikacije donosi mnogo životnija izvješća i kritičke osvrte koji se najčešće ne nalaze u često suhoparnim i birokratskim izvještajima sa sjednica.

Samoupravni preobražaj kulture i uspostava SIZ-ova kulture na razini općina

Uz spomenuti novi Ustav iz 1974. te Zakon o udruženom radu iz 1976., ključan je bio i Deseti kongres Saveza komunista Jugoslavije (SKJ), održan 1974., čiji zaključci formiraju buduću kulturnu politiku, tj. pitanja „o shvaćanju kulture, o slobodi stvaralaštva, o kulturi radnog čovjeka, o ravnopravnom razvoju kultura naroda i narodnosti, o subjektima kulturne politike, kulturnoj akciji, itd.”4 Pritom se pojam „samoupravne kulture”, odnosno „socijalističkog samoupravnog poimanja kulture", stvara u vlastitoj teoriji i kulturnoj politici, a obuhvaća raspon od partijske politike i radničkih (amaterskih) kulturnih praksi do pitanja humanizacije rada, međuljudskih odnosa i kulture kao načina života. Glavna definicija kulture u samoupravnom društvu proizašla je iz Marxove definicije kulture kao „sadržaju i suštini života”, pa je tako i temelj za samoupravni preobražaj kulture trebao biti u „univerzalnoj stvaralačkoj i samostvaralačkoj djelatnosti kojom čovjek potvrđuje mnogostranost svoga bića". Samoupravni preobražaj kulture stoga je trebao ukinuti jednakoznačnost između pojmova kulture i umjetnosti koje se jugoslavenska socijalistička kultura unatoč svim pokušajima dotad nije uspijevala riješiti. Prema tome, umjetnost je smatrana „najslobodnijim oblikom čovjekova stvaralaštva”, a kultura je trebala biti ugrađena „u cjelinu društvene reprodukcije”. ${ }^{6}$ Točnije, samoupravni preobražaj kulture trebao je maknuti definiciju kulture iz čiste sfere umjetničkoga stvaralaštva te ju je definirao kao sveukupnost radničkoga života i priliku za potpuno samoostvarenje svakoga pojedinca.

Zbog toga bi se moglo reći da je i pitanje radničkoga sudjelovanja u samoupravno preobraženim kulturnim aktivnostima bilo dvojako: kako uključiti radnike u produkciju kulture i, mnogo važnije, kako kulturu transformirati u način života. Sindikati su, naravno, imali važnu ulogu u primjeni ideološ-

GRBAC, Kultura na društvenoj pozornici, 14-15.

Isto, 3 .

ĐOKIĆ, Samoupravni preobražaj kulture, 21. 
kih postavki u svakodnevnom životu radnika i njihovu radnom okruženju, pa tako i kulturi. U sindikalnom udžbeniku Samoupravni preobražaj kulture iz 1984. autor Ljupče Đokić pristupačnim jezikom objašnjava teorijske paradigme samoupravne kulture i primjere njezine primjene u tvornicama. Vođen Marxovom definicijom kulture, Đokić zagovara premošćivanje podjele između svijeta materijalnoga i duhovnoga stvaralaštva, pri čemu su glavnu ulogu trebale imati osnovne organizacije udruženog rada (OOUR), ali samo ako bi i one same u svojem temelju bile kulturnom organizacijom. Takav se samoupravni preobražaj kulture i odnosa među radnicima trebao očitovati u afirmaciji kreativnosti u radu, humanizaciji radnoga procesa i radnoga okruženja, planiranju kulturnoga razvoja i izgradnji organizacijskih i kadrovskih osnova.

S obzirom na to da novim Ustavom i Zakonom o udruženom radu OOUR-i po samoj definiciji nisu samo pravno zamijenili poduzeća, nego je osnovna premisa bila da radnici na svojim radnim mjestima društvenim dogovorom, tj. zastupanjem svojih potreba i nalaženjem kompromisa s drugim radnicima s kojima udružuju sredstva i rad, ostvaruju svoja društveno-ekonomska i druga prava, i organiziranje kulture kao integralnoga dijela udruženoga rada obuhvaćalo je dva osnovna aspekta. Kao prvo, radnici su bili smatrani glavnim nosiocima kulturnoga razvoja, pa su njihove potrebe, želje i interesi shodno tome trebali biti i polazište stvaranja kulture, koja se nije mogla stvarati mimo njih, nego s njihovom izravnom participacijom. Drugi aspekt pokrivao je financijski dogovor, tj. sredstva za razvoj kulture, koja su se osiguravala neposrednim i slobodnim dogovaranjem između kulturnih radnika i radnika u udruženom radu materijalne proizvodnje definiranih samoupravnim sporazumom.

U eseju Kulturne djelatnosti u organizacijama udruženog rada iz 1978. kulturna radnica Vesna Kauzlarić postavlja temeljna pitanja samoupravne kulture koja se redovito provlače u raspravama tijekom 70-ih i 80-ih:

„Što zapravo znači planiranje razvoja kulture na osnovi kulturnih potreba radnih ljudi u OUR-ima i građana u mjesnim zajednicama? To prije svega znači ispitivanje i utvrđivanje potreba radnih ljudi za kulturnim sadržajima, zatim razvijanje želja i interesa, imajući pritom na umu 'da radni ljudi, proizvodeći materijalna dobra, istovremeno sudjeluju i u stvaranju kulturnih'?’

Na primjeru Zagreba ona analizira srednjoročne planove razvoja kulturnih djelatnosti na iskustvima nekoliko radnih organizacija te zaključuje da je većina planiranih aktivnosti fokusirana na posjete kazalištu, muzejima i umjetničkim galerijama, ili dolazak umjetnosti u same tvornice. Jedina aktivna uloga radnika u stvaranju kulture pronalazi se u amaterskim kulturnim aktivnostima pojedinih radnika, koje Kauzlarić identificira kao entuzijaste „koji u radnim organizacijama postaju nosioci kulturnih djelatnosti. To su ponekad ljudi bez školskih kvalifikacija, ali s divnim razumijevanjem za sve

7 KAUZLARIĆ, „Kulturne djelatnosti u organizacijama udruženog rada”, 56. 
umjetničke i humane sadržaje. Ponekad su to ljudi široke kulture i velikih organizacionih sposobnosti". ${ }^{8}$

U njima ona pronalazi prave nosioce kulturnih promjena koje će se odviti u radnoj zajednici, ali i one koji će potaknuti ostale da se kulturno obrazuju te preuzmu kulturu u svoje ruke, što bi dovelo do konačnoga samoostvarenja radnika. Tek bi tada „zahtjev za ovladavanje dijelom dohotka koji udruženi radnici izdvajaju za kulturu bio ispunjen stvarnim sadržajem i ne bi ostao puka fraza koju ponavljamo svake godine kada na zborovima radnika treba donijeti odluku o potpisivanju samoupravnih sporazuma o udruživanju rada i sredstava u samoupravnoj interesnoj zajednici kulture". ${ }^{9}$

Samoupravne interesne zajednice kulture osnovane su na temelju Ustava iz 1974., a cilj im je bio da radnici u OUR-ima kulture te radnici u OUR-ima i građani u mjesnim zajednicama (MZ) na principima međusobnoga pomaganja i solidarnosti zadovolje svoje vlastite i zajedničke potrebe i interese u području kulture. SIZ-ovi kulture bili su zamišljeni kao delegatski sustav s dva vijeća - vijećem davalaca usluga (tj. kulturnih radnika) i vijećem primalaca usluga (tj. radnika i građana). Delegati OUR-a i mjesnih zajednica trebali su s delegatima OUR-a kulture na skupštini zajednički donositi godišnji i petogodišnji plan razvoja kulture i kulturnih programa u određenoj općini. Birani su na demokratskim izborima svake četiri godine među radnim kolektivom ili u mjesnoj zajednici. Delegat je, kao i za druge funkcije u OUR-ima i mjesnim zajednicama, mogao biti svatko, iako su to najčešće bili upravo oni pojedinci koji su gajili poseban interes za kulturu ili umjetnost, s time da je njihova funkcija bila predstavljati interese svoje male zajednice te povratne informacije prenositi svojoj delegatskoj bazi. Prvi SIZ-ovi kulture organizirani su odmah nakon donošenja novoga Ustava, a do 1983. postojalo je 113 općinskih SIZ-ova te Republički SIZ kulture. Zbog daljnjega unapređenja i regulacije samoupravljanja u kulturi 1983. donesen je i Zakon o samoupravnim interesnim zajednicama kulture.

Odnosi slobodne razmjene rada u kulturi služili su usklađivanju kulture kao specifične društvene aktivnosti s udruženim radom u cjelini te da bi ubrzali proces samoupravnoga preobražaja kulture. To se moglo postići samo ukidanjem posredovanja između kulture i udruženoga rada, koje se dotad manifestiralo kroz državne intervencije ili samovolju radnika u kulturi. Tako primjerice Đokić razaznaje budžetsku fazu koja je dominirala do sredine 60-ih godina, za koju je bilo karakteristično financiranje kulturnih aktivnosti iz sredstava prikupljenih porezom, a ona se troše na većinom tradicionalne institucije kulture. Pritom je kulturni rad radnika sveden na kulturno-umjetničke samoaktivnosti. S druge strane tzv. fondovska faza, koja je trajala od sredine 60 -ih do sredine 70 -ih, obilježena je prikupljanjem sredstava u fondove kulture na čelu kojih sjede upravni odbori sastavljeni od kulturnih radnika.

8 Isto.

9 ĐOKIĆ, Samoupravni preobražaj kulture, 21. 
Iako u toj fazi dolazi do stanovite demokratizacije kulture, još uvijek je bio primjetan određeni oblik kulturnoga elitizma koji je svodio „sve radnike i građane na ulogu pasivnih konzumenata kulture", a kulturni radnici smatrali su se prosvijećenima jer ,jedini znaju kakva kultura treba narodu”. ${ }^{10}$ Nijedna od dviju prošlih opcija nije zadovoljavala osnovne postulate demokratizacije kulture, tj. da sami „radni ljudi” odlučuju ne samo o tome gdje će, kako i koliko njihova novca biti utrošeno na kulturu nego i o njezinu sadržaju, tj. da aktivno sudjeluju u stvaranju kulture po svačijoj mjeri, ne samo tradicionalnih kulturnih institucija kao u budžetskoj fazi, ili često elitistički nastrojenih kulturnih radnika kao u fondovskoj fazi.

Zato su osnivanje SIZ-ova kulture i najavljeni samoupravni preobražaj kulture započet 1974. trebali konačno demokratizirati kulturu do krajnjih granica i to je, kroz slobodnu razmjenu rada u kulturi i uspostavu delegatskoga sustava, bio najradikalniji zahvat u kulturi od samoga uvođenja socijalizma trideset godina prije. Na zajedničkoj sjednici Savezne konferencije Socijalističkoga saveza radnog naroda Jugoslavije za društveno-ekonomske odnose u društvenim djelatnostima i Sekcije za kulturu Republičke konferencije Socijalističkoga saveza radnog naroda Srbije održanoj krajem 1974. zaključeno je da SIZ-ovi kulture imaju zadatak da „doprinesu prevazilaženju postojećeg sužavanja kulture na kulturne institucije i kulturne delatnosti, da stvaralaštvu, i to integralno shvaćenom, osiguraju smisao autorskog i društvenog čina". ${ }^{11}$ Pitanje kulture pritom se trebalo izmjestiti iz najužega stručnog polja te je valjalo proširiti sam pojam kulturnih djelatnosti, što bi na kraju dovelo do razvoja kulture rada u OUR-ima i društvu u cjelini.

Zaključci s te zajedničke sjednice 1974. definirali su što je i na koji način trebalo poboljšati uspostavom SIZ-ova kulture:

„Radni ljudi, udruženi u SIZ-ove kulture, treba da donose kompetentne planove samoupravnog razvoja kulture, da te planove usklađuju i sa suštinom kulturnog stvaralaštva i sa potrebama radnih ljudi za kulturom. U tom smislu ti planovi treba da budu kreativni izraz planova organizacija udruženog rada u zadovoljavanju kulturnih potreba radnika, planova mesnih zajednica i širih društvenih planova, ali i konstitutivni element društvenog plana društveno-političke zajednice."

U teoriji, to je značilo da su radnici u OUR-ima i građani u mjesnim zajednicama s radnicima u OUR-ima kulture udruživali rad (kulturnih radnika) i sredstva (radnika u OUR-ima i građana u mjesnim zajednicama) na obostranu korist. Radnici u OUR-ima i građani u mjesnim zajednicama na taj su način mogli zadovoljiti svoje i općedruštvene kulturne potrebe, a radnici u

10 Isto, 23.

11 SR-AJ-320-SKNK, kut. 31, Opšti materijali o kulturi, prosveti i nauci, „Stavovi i mišljenja o ostvarivanju ustavne koncepcije interesnih zajednica kulture".

12 Isto. 
OUR-ima kulture osiguravali su svoj dohodak i socioekonomski se izjednačavali s ostalim radnicima.

Sami odnosi slobodne razmjene rada u kulturi mogli su biti neposredni i posredni. Neposrednom razmjenom rada smatralo se onu u kojoj su kulturni radnici izravno dogovarali s radnim ljudima koje su njihove potrebe koje treba zadovoljiti, tj. između pojedinoga OUR-a materijalne proizvodnje ili mjesne zajednice i pojedinoga OUR-a kulture (ili kulturne institucije), a posredna razmjena rada bila je ona koja se odvijala preko delegata u OUR-ima i SIZ-ovima kulture. Problemi u odnosima slobodne razmjene rada javili su se već u samome početku, pogotovo pri posrednoj razmjeni rada. Primjerice, na sastanku republičkih i pokrajinskih sekretara za kulturu 1976., na kojemu se raspravljalo o Nacrtu zakona o udruženom radu i kulturi, zamjenik pokrajinskoga sekretara za obrazovanje, nauku i kulturu Socijalističke Autonomne Pokrajine Vojvodine Laslo Varga napominje da su SIZ-ovi kulture preuzeli mnogo obrazaca rada od prethodnih modela programiranja i financiranja kulture te zaključuje da „još ima dosta statističko-administrativnog i fiskalnog obeležja”. ${ }^{13}$

Iako su neposredni odnosi slobodne razmjene rada trebali dodatno poticati oslobađanje kreativnosti i humanizaciju rada, ona je u svojim počecima predstavljala još veći problem nego ostali novouvedeni oblici upravljanja kulturom. Posebno su problematične bile tradicionalne institucije i ustanove kulture poput muzeja i kazališta. Kako ističe Varga, čak i kad su tradicionalne kulturne institucije poticale neposrednu razmjenu rada, to je više izgledalo „kao sticanje uzgrednog dohotka ili potpuno isključivanje dohotka, a mnogo manje kao zasnivanje nekog novog odnosa, što bi se moglo nazvati samoupravno dogovornim vidom neposredne razmene rada”. ${ }^{4}$ I Aktiv SKJ primijetio je 1977. da se „slobodna razmjena rada” većinom svodila na najobičnije posredovanje između tradicionalnih kulturnih institucija i radnika - udruženih proizvođača, tj. na distribuciju ulaznica, organiziranje posjeta kulturnim institucijama ili kulturnim manifestacijama ili njihovo primanje u goste. ${ }^{15}$

Dok je velik dio kulturnih radnika još uvijek zauzimao elitistički stav, OUR-ima materijalne proizvodnje manjkalo je inicijative i kreativnih snaga koje bi zastupale stavove ostalih radnika. Tako Aktiv SKJ dalje navodi da se unatoč proklamiranim promjenama kulturi i dalje prilazilo većinom preko otkupa gotovih proizvoda kulture, pa su radnici u tim odnosima još uvijek bili pasivni konzumenti kulturnih programa koji su nastali mimo i bez njih. Aktiv SKJ stoga zaključuje:

13 SR-AJ-320-SKNK, kut. 31, Opšti materijali o kulturi, prosveti i nauci, „Javna diskusija o Nacrtu zakona o udruženom radu i kulturi”.

14 Isto.

15 SR-AJ-463-SKPZJ, kut. 7, Materijali sa sednica. 30. Sednica Sekretarijata ZKPOJ, 5. 10. 1977. 
„Jednosmerno oblikovanje kulturne politike i to iz pravca kulturnih institucija ili različitih privatnih, grupnih, elitističkih i drugih pobuda, biće prisutno sve dok OUR-i i mesne zajednice budu bez razvojnog kulturnog života u svojoj sredini, bez kulturnih programa. Jer, delegat mora imati platformu za svoje delovanje u svim oblicima slobodne razmene rada, mora polaziti od programa sopstvene OUR ili MZ. U suprotnom, on je pasivni pratilac kulturnih programa nastalih bez njega."16

Iako je postojalo stanovito razumijevanje za manjkavosti u uspostavljanju novoga sustava organiziranja kulture i dobronamjernosti prilikom početničkih grešaka, Stipe Šuvar, tada u ulozi republičkoga sekretara za prosvjetu, kulturu i fizičku kulturu, već je 1976. napomenuo da zabrinjava činjenica da se dvije godine poslije velik dio općinskih SIZ-ova nije konstituirao, a oni postojeći i dalje su reproducirali stare budžetsko-fondovske obrasce djelovanja. ${ }^{17}$ Šuvarova strahovanja potvrdio je i Aktiv SKJ, koji je na spomenutoj sjednici iznio nekoliko gorućih problema u funkcioniranju SIZ-ova kulture - nepostojanje kriterija za vrednovanje kulturnih programa, zanemarivanje društvene produktivnosti i razvoja samoupravljačke svijesti, tretiranje SIZ-ova za kulturu kao mjesta distribucije novca - te zaključio da se jugoslavensko društvo suočava „sa pokušajima adaptiranja umesto samoupravnog transformisanja kulturnog i društvenog delovanja kulturnih institucija”. ${ }^{18}$

SIZ-ovi kulture bivali su kritizirani ne samo zato što su djelomično tek zamijenili fondove za kulturu nego i zato što nisu stimulirali neposrednu slobodnu razmjenu rada, kao i zato što nisu ispunili svoju prosvjetnu misiju u diseminaciji znanja i iskustva u planiranju kulturnih aktivnosti. Međutim, kako primjećuje Republička koordinacija za SIZ-ove Socijalističke Republike Hrvatske (SRH), a slično napominje i Šuvar u svojem izlaganju, mnogi OUR-i materijalne proizvodnje nisu uspjeli utvrditi svoje potrebe u godišnjim i srednjoročnim planovima, nego su inicijativu još uvijek preuzimali OUR-i radnika u kulturi i organi SIZ-ova, na taj način i dalje podržavajući dihotomiju između davalaca i primalaca usluga. ${ }^{19}$ Kao što je pokazalo istraživanje koje je 1978. i 1979. proveo Zavod za kulturu Hrvatske, samo 21 od 131 ispitanog OUR-a imao je nekakvu vrstu plana ili programa kulturnoga razvoja vlastitoga OUR-a, a čak su i oni redovito bili sačinjeni najvećim dijelom od nabrajanja kulturno-umjetničkih samoaktivnosti radnika i kulturnih manifestacija koje su se održavale unutar OUR-a.

16 Isto.

17 ŠUVAR, „Samoupravne interesne zajednice ne smiju biti jedini činioci kulturne politike”, Bilten Republičke samoupravne interesne zajednice kulture (dalje: Bilten RSIZK) (Zagreb), 1 (1976), 35.

18 SR-AJ-463-SKPZJ, kut. 7, Materijali sa sednica. 30. Sednica Sekretarijata ZKPOJ, 5. 10. 1977.

19 „Program aktivnosti u izradi i zaključivanju samoupravnih sporazuma o slobodnoj razmjeni rada za 1977. godinu”, Bilten RSIZK, 6 (1976), 22. 
Analiza samoupravnih sporazuma koju je proveo Republički SIZ za kulturu pokazala je da je većina godišnjih i srednjoročnih programa kulturnoga razvoja OUR-a u materijalnoj proizvodnji bila potpuno formalne naravi, gdje su samo nabrojene točke aktivnosti na jednoj ili dvije stranice. Drugi dio programa bio je „deklarativnog i proklamacijskog značaja, bez podataka o opsegu pojedinih djelatnosti ili aktivnosti, odnosno akcionih mjera", a samo je manji dio programa imao detaljno razrađene aktivnosti, neki čak i do razine da su bili predetaljni za uvrštavanje u samoupravni sporazum..$^{20} \mathrm{I}$ sami samoupravni sporazumi varirali su od općine do općine, razlikujući se po nazivima i kvaliteti sadržaja, pri čemu ponekad naziv uopće ne bi odgovarao sadržaju. To jest, neki sporazumi često su izgledali više kao odluka o porezima i doprinosima za zadovoljavanje potreba u kulturi, a manje kao razvijanje suodnosa između dva jednakopravna aktera koja zajednički određuju potrebe u kulturi radnika i građana. ${ }^{21}$ Slično kao s uspostavom i funkcioniranjem SIZova kulture, pisanjem godišnjih i srednjoročnih programa, tako su i samoupravni sporazumi često odražavali ostatke prijašnjih bilo budžetskih, bilo fondovskih načina financiranja kulture.

Sindikalni radnik Ljupče Đokić iznio je u spomenutom sindikalnom udžbeniku o samoupravljanju u kulturi tri osnovna uzroka problema koji su se javljali u djelovanju SIZ-ova kulture. Uz one koji otežavaju djelovanje sustava samoupravnoga interesnog organiziranja kao cjeline, navodi i uzroke koji sputavaju odgovarajuće uspostavljanje odnosa slobodne razmjene rada te uzroke koji otežavaju efikasnije djelovanje delegatskoga sustava. ${ }^{22} \mathrm{~S}$ obzirom na opseg rada i izlaženje iz teorijskoga okvira bavljenja pitanjem kulture, prva dva uzroka neće biti detaljno analizirana. Djelovanje delegatskoga sustava kao temelja funkcioniranja SIZ-ova kulture, omogućavanja posredne i neposredne razmjene rada i širenja demokratskih procesa u svojim radnim zajednicama bit će analizirano na primjeru općine Pule od 1970. do 1990. godine.

Samoupravljanje u kulturi u općini Pula kroz delegatski sustav

Općina Pula 1971. bila je šesta po broju stanovnika u SRH, spadajući u drugu kategoriju veličine općina (prvom smatrajući one s preko 100 tisuća stanovnika). Kao visoko urbanizirana općina sa samo 1,3 posto stanovništva zaposlenog u primarnom sektoru, znatan broj kulturnih institucija i manifestacija zajedno s pripadajućom infrastrukturom odgovarao je najvećim dijelom društvenoj poziciji koju je Pula imala u republici, a i u federaciji. Prema istraživanju iz 1978., sedam jedinica kulturnih organizacija s dvadeset podružnica djelovalo je u Puli pod ingerencijom SIZ-a za kulturu te jedna izvan

20 „Analiza samoupravnih sporazuma o Programu kulturnog razvoja, o udruživanju sredstava, te kriterijima i mjerilima za slobodnu razmjenu rada za 1977.", Bilten RSIZK, 12 (1977), 40.

${ }^{21}$ Isto, 38-39.

22 ĐOKIĆ, Samoupravni preobražaj kulture, 29. 
njegove nadležnosti, koja se bavila izdavačkom i novinarskom djelatnošću. U gradu se održavao Festival jugoslavenskoga igranog filma kao najvažnija manifestacija općejugoslavenskoga karaktera, a glavne kulturne institucije uključivale su Arheološki muzej, Muzej narodne revolucije Istre, Naučnu biblioteku, Općinsku knjižnicu i čitaonicu, Istarsku scenu (tj. Centar za scenske i likovne umjetnosti), Istrakino, Katedru Čakavskog sabora, Povijesno društvo Istre te Savez amaterskih kulturno-umjetničkih društava (SAKUD). Amaterski kulturno-umjetnički rad razvijao se u dvadeset samostalnih amaterskih društava, 22 sekcije amaterskih društava te sedam kulturnih domova. Infrastrukturno gledano, općina Pula bila je iznadprosječna u broju stanovnika na jedno sjedalo u dvoranama radnih organizacija kulture i čitaonicama radnih organizacija, iako je tijekom čitavoga razdoblja 70 -ih i 80-ih ostalo otvoreno pitanje renovacije zgrade kazališta, što je za visokorazvijenu općinu bilo poprilično problematično društveno i kulturno pitanje.

S obzirom na položaj kulture u općini Pula u kontekstu SRH, ne čudi što je među prvima u republici osnovala Zajednicu za kulturu već krajem 1972., kao prijelazno tijelo između općinskoga fonda za kulturu i SIZ-a kulture, koji je tek bio u nacrtima. Privremena skupština Zajednice razmatrala je nacrt novoga Ustava i pripremala teren za uspostavu SIZ-a kulture raspravljajući o načinima biranja delegata za SIZ, organizaciji domova, tj. vijeća unutar SIZ-a, te pripremala smjernice za financiranje kulturnih aktivnosti u općini. Iako su u privremenoj skupštini Zajednice sudjelovali probrani radnici i građani zajedno s radnicima kulturnih organizacija, stajalište Zajednice bilo je da se budući predstavnici, odnosno delegati, trebaju birati u izbornom delegatskom postupku u OUR-ima i mjesnim zajednicama. Kao što donosi prvi broj Kulturnoga vjesnika, glasila SIZ-a kulture općine Pula, biranje članova budućega SIZ-a kulture kroz delegaciju

„ne samo da je mnogo racionalnije i jednostavnije, već omogućuje da se na nivou delegacije konfrontiraju, usporede i usaglase interesi različitih oblasti podložnih reguliranju putem interesnih zajednica - sa stajalištima što će ih delegat te delegacije zastupati u skupštini društveno-političke zajednice". ${ }^{23}$

Daljnja demokratizacija kulture trebala je biti omogućena dvodomnim konstituiranjem Skupštine, prema kojem bi u jednom domu vijećali delegati OUR-a kulture i radnici u kulturi, a u drugom domu delegati OUR-a materijalne proizvodnje i mjesnih zajednica, što bi dodatno osiguralo sporazumno rješavanje problema u kulturi. Na taj bi način radnici u kulturi „ostali gospodari uvjeta vlastitog rada”, a drugi bi radnici „ostali gospodari svojeg dohotka” ${ }^{24}$ Važno je napomenuti da je već na početku definiranja uloge SIZ-a kulture upozoreno na to da će dvodomni i delegatski sustav djelomično komplicirati i usporiti donošenje odluka, no to se smatralo cijenom demokratskih

23 A. C., „Aktualni zadaci Zajednice za kulturu”, Kulturni vjesnik (Pula), 1 (1974), 4-5.

24 Isto. 
procesa i stvaranja novih odnosa koji su isključivali nadglasavanje i naređivanje te svu nadu polagali u međusobni dogovor i solidarnost.

Godine 1974. činilo se da u općini Pula postoje snažni temelji za najavljeni samoupravni preobražaj kulture. Već je dvije godine postojala Zajednica za kulturu koja je pripremala godišnje programe kulture, formirala svoju stručnu službu te izdavala glasilo Kulturni vjesnik. ${ }^{25}$ Kulturni vjesnik pritom je bio jedan od rijetkih stručnih biltena SIZ-ova kulture - Bilten Republičke samoupravne interesne zajednice kulture 1979. donosi vijest da u SRH postoje samo tri biltena SIZ-ova kulture, od kojih posebno ističe pulski, koji izlazi čak četiri puta godišnje, a dostavlja se svim delegatima, delegacijama i društveno-političkim, kulturnim i javnim radnicima. ${ }^{26} \mathrm{~S}$ obzirom na to da se tijekom godina osim samih izvještaja sa sjednica, priloženih odluka i programskih i financijskih planova u Kulturnom vjesniku često mogu naći i izravna iskustva s terena, $\mathrm{tj}$. analiza kulture u različitim OUR-ima i mjesnim zajednicama, bilo pozitivna ili negativna, može se zaključiti da su stručni suradnici SIZ-a kulture općine Pula samoupravni preobražaj kulture shvatili ozbiljno. S rasformiranjem Skupštine Zajednice za kulturu i pripremama za prve izbore delegata za novoosnovani SIZ kulture općine Pula Kulturni vjesnik objavio je analizu djelovanja Zajednice, detaljno navodeći pozitivna i negativna iskustva rada $u$ jednom eksperimentalnom obliku upravljanja kulturom. Kao jedna od pozitivnih stvari istaknuto je prevladavanje negativnih praksi naslijeđenih iz Fonda za unapređivanje kulturnih djelatnosti, koje su se prvenstveno odnosile na sukobe oko financijskih sredstava između predstavnika kulturnih organizacija, zatim nesudjelovanje ostalih članova Upravnoga odbora u aktivnostima Fonda te materijalnu nesigurnost radnika u kulturi uzrokovanu minimalnim predviđenim financijskim sredstvima. Stoga se na osnivanje Zajednice gledalo kao na izvjestan korak naprijed u unapređivanju demokratskoga suodlučivanja, pa je u izvještaju u Kulturnom vjesniku ponosno naglašeno da je kroz Zajednicu prošlo više od stotinu ljudi, predstavnika kulturnih, proizvodnih i društveno-političkih organizacija te mjesnih zajednica koji su u suradnji sa stručnim osobljem sudjelovali u raznim izvršnim i stručnim tijelima. ${ }^{27}$

Skupština SIZ-a kulture konstituirana 1975. bila je, kako je i planirano, dvodomna, s predviđena dva vijeća i šezdeset delegata. Vijeće korisnika kulturnih dobara i vrijednosti sastojalo se od četrdeset delegata, od kojih su trideset delegirali OUR-i i deset mjesne zajednice, a Vijeće radnika koji obavljaju kulturne djelatnosti imalo je dvadeset delegata, od kojih deset iz OUR-a kulturnih organizacija, sedam iz amaterskih kulturnih društava i tri iz udruženja samostalnih kulturnih radnika i umjetnika. ${ }^{28}$ Nakon prvih izbora na konferencijama delegacija radnih ljudi u OUR-ima i građana u mjesnim

25 M. S., „Predstoje važni zadaci”, Kulturni vjesnik, 3 (1974), 4.

26 „Analiza stanja informiranja interesnih zajednica u oblasti kulture udruženih RSIZK za 1979.”, Bilten RSIZK, 28 (1980), 59.

27 „Dragocjeno iskustvo”, Kulturni vjesnik, 7 (1974), 3-5.

28 „Dva vijeća”, Kulturni vjesnik, 7 (1974), 8-9. 
zajednicama izabrano je 57 delegata s obzirom na to da u općini Pula 1974. nije postojalo nijedno udruženje samostalnih kulturnih radnika i umjetnika, stoga nije ni bilo moguće izabrati delegate iz te oblasti. Prema Samoupravnom sporazumu o osnivanju SIZ-a kulture općine Pula, delegati su trebali određivati i voditi kulturnu politiku na razini općine, planirati razvoj kulture u općini, upravljati sredstvima za izvršavanje kulturnih programa, utvrđivati godišnje, srednjoročne i dugoročne programe kulturnoga razvoja općine i slično. Za uspješan rad delegatskoga sustava bilo je potrebno obvezati delegate da o svojem radu informiraju svoje delegacije, konzultiraju se s njima prije donošenja stavova o pojedinim pitanjima te zastupaju zajedničke interese svoje delegacije, pogotovo kad se radilo o utvrđivanju programa kulturnoga razvoja te o udruživanju i visini sredstava za kulturne aktivnosti. ${ }^{29}$

Već je praksa u Zajednici za kulturu od 1972. do 1974. pokazala koje su se manjkavosti mogle očekivati u funkcioniranju delegatskoga sustava. Velik dio delegata nije aktivno sudjelovao u radu Skupštine, a bilo je i onih koji se uopće ili gotovo uopće nisu pojavljivali na sjednicama, što je ponekad rezultiralo odgađanjem sjednica zbog nemogućnosti ispunjavanja kvoruma. ${ }^{30}$

Kako piše Kulturni vjesnik,

„dio krivice je na njima, ali takva neaktivnost dobrim dijelom proistekla je iz nezainteresiranosti onih kolektiva, koji su te delegate birali, za njihov rad i općenito za kulturnu problematiku. Dio krivice treba tražiti i u nedovoljno razvijenom sistemu informiranja u Zajednici za kulturu, kao i u pasivnom odnosu društveno-političkih organizacija u udruženom radu, mjesnim i drugim zajednicama za rad Zajednice za kulturu i za probleme kulture općenito". ${ }^{31}$

Da problem nije bio samo i isključivo (ne)odgovornost delegata govori i iskustvo Ivana Štekara, referenta za propagandu i kulturne odnose u Hotelskom poduzeću Veruda, koji je bio članom Skupštine i Izvršnoga odbora Zajednice za kulturu. Kao što je iznio u intervjuu za Kulturni vjesnik, postao je delegatom na prijedlog svoje radne organizacije i Općinskoga sindikalnog vijeća u prosincu 1972., nakon čega više nije imao nikakva kontakta sa svojom delegacijom na radnome mjestu u vezi s aktivnostima u Zajednici za kulturu, što je rezultiralo time da je pri odlučivanju više zastupao svoj nego stav svoje radne organizacije:

„Sve se svodi na moj glas. Moja radna organizacija, a vjerujem da je tako i kod drugih, nije uvidjela mogućnost svog utjecaja na kulturnu politiku i kulturne sadržaje u općini pa nije do sada pokazala ni interesa za uspostavljanje drugačijeg, aktivnijeg odnosa prema meni, odnosno preko mene Zajednici za kulturu. Naravno da u takvoj situaciji nisam u mogućnosti prenositi stavove svoje radne organizacije, već djelujem individualno, ne kao predstavnik."32

29 M. SINČIĆ, „Delegati”, Kulturni vjesnik, 7 (1974), 2.

30 „Peta sjednica skupštine”, Kulturni vjesnik, 3 (1974), 10.

31 „Dragocjeno iskustvo”, Kulturni vjesnik, 7 (1974), 3-5.

32 „Nitko od mene ne traži odgovornost”, Kulturni vjesnik, 3 (1974), 6. 
Zbog takvih i sličnih iskustava Miroslav Sinčić, i sam radnik u kulturi, u drugome broju Kulturnoga vjesnika upozoravao je na opasnost nastavka takve prakse u novoosnovanim SIZ-ovima kulture, što bi dugoročno za posljedicu moglo imati neuspjeh samoupravljanja u kulturi i onemogućavanje kulturnoga razvoja. ${ }^{33}$ Međutim, svim upozorenjima unatoč, iskustva i ispovijesti poput Štekarove pojavljivali su se još duboko u 80-ima.

Rekapitulacija prve godine djelovanja SIZ-a kulture općine Pula iznijeta u članku „Neodgovornost ili...” u Kulturnom vjesniku 1976. donijela je konkretne podatke o aktivnosti delegata. Posebno je problematična bila aktivnost delegata u Vijeću korisnika, što ne čudi s obzirom na to da su delegati Vijeća radnika koji obavljaju kulturne djelatnosti imali prednost iskustva radeći u kulturnim institucijama i posjedujući ipak kakvo-takvo znanje o programiranju i financiranju kulture, a i osobni dohodak ovisio im je o odlukama SIZ-a kulture. S druge strane delegati u Vijeću korisnika još su učili osnove slobodne razmjene rada te su morali shvatiti koja je njihova odgovornost prema delegacijama koje su ih izabrale, bilo u OUR-ima ili mjesnim zajednicama, kao i uloga u samoupravnom preobražaju kulture. Tako je u prvoj godini Skupštine SIZ-a kulture općine Pula samo sedam delegata iz Vijeća korisnika prisustvovalo svim sjednicama, a gotovo isti broj, njih šest, nije se odazvao ni na jednu. Neke sjednice zamalo se nisu održale jer se jedva osigurao kvorum, a i on se često popunjavao hitnim telefonskim pozivima koje su u posljednji trenutak obavljale stručne službe. ${ }^{34}$ Problem kvoruma trajao je do samoga raspada $\mathrm{dr}$ žave i, unatoč opetovanim pozivima delegatima da svoju dužnost obavljaju ozbiljno, telefonska zivkanja i „lociranje” nedostajućih delegata uoči početka sjednice bili su svakodnevica stručne službe SIZ-a kulture, a čak se i 1986. događalo da se sjednica odgodi zbog nemogućnosti postizanja kvoruma. ${ }^{35}$

Dio problema vezanih uz delegate sigurno se odnosio na razinu osobne odgovornosti pojedinaca. Neki delegati jednostavno nisu bili zainteresirani za aktivno sudjelovanje na sjednicama, što je primjerice 1979. priznala i delegatkinja Elektroistre Janja Rogonjić u razgovoru za Kulturni vjesnik. Međutim, ona je nedostatak vlastite motivacije pripisivala i lošoj organizaciji sjednica, koje su redovito kasnile zbog popunjavanja kvoruma, što je često izazivalo nervozu delegata spremnih na raspravu. A čak i kad bi se rasprava povela, „mnogi diskusanti na sjednicama Skupštine SIZ-a drže dugačke monologe o vlastitim stavovima i mišljenjima, umjesto da kratko i jasno iznose stavove svoje delegacije". ${ }^{36}$ Slične napomene drugih delegata pokazivale su da je problem neaktivnosti delegata, pogotovo onih u Vijeću korisnika, ipak bio složeniji.

33 M. SINČIĆ, „Delegati”, Kulturni vjesnik, 7 (1974), 2.

34 „Neodgovornost ili...”, Kulturni vjesnik, 10 (1976), 3-4.

35 M. SINČIĆ, D. ŠTORGA, „Predugo uhodavanje”, Kulturni vjesnik, 24 (1981), 2-3; „Izvještaj o radu Skupštine u mandatnom razdoblju od 1982. do 1986.”, Kulturni vjesnik, 36 (1986), 16-17.

36 Antonio FRACCARO, Enio BUGARIN, „Kulturnom životu radnika posvećuje se neznatna briga", Kulturni vjesnik, 15 (1979), 3-4. 
Velik dio problema bio je vezan za nedostatnu transformaciju OUR-a, pogotovo onih materijalne proizvodnje, za sudjelovanje u izgradnji kulturne politike. Znatan dio njih nije imao utvrđene godišnje ni srednjoročne programe potreba u kulturi, što je značilo da radnici nisu mogli definirati koje točno programe žele konzumirati, u čemu i na koji način žele sudjelovati. Stoga su pri izradi samoupravnih sporazuma često bili svedeni na pasivne potpisivače planova i odluka koje su izrađivali članovi OUR-a kulturnih i društvenih djelatnosti, fokusirajući se eventualno na iznos koji su izdvajali iz svojega dohotka za ostvarivanje tih planova i programa. ${ }^{37}$ Kao što sažima Bilten Republičke samoupravne interesne zajednice kulture, „planovi i programi kulturnog razvoja javljaju se još uvijek kao ponuda, a manje kao iskazivanje potreba radnika i radnih ljudi”, pa „se kultura i tretira kao potrošnja, umjesto da bude sastavni dio društveno-ekonomskog razvoja društva i element jačanja njegove reprodukcione sposobnosti" ${ }^{38}$

Pojedini delegati trudili su se informirati svoje delegacije u OUR-ima i mjesnim zajednicama telefonskim razgovorima i razglasnim uređajima, plakatima i panoima, prilozima u tvorničkim listovima te na sastancima radnih organizacija. ${ }^{39}$ Velike organizacije, poput Složene organizacije udruženog rada (SOUR) Uljanik, s jedne strane imale su veće resurse za distribuciju materijala, ali je s druge strane procedura prenošenja informacija od delegata SIZ-a kulture do krajnjih korisnika - radnika u radnim zajednicama - bila previše duga i komplicirana da bi omogućila efikasno djelovanje. Predsjednik konferencija delegacija SOUR-a Uljanik Vladimir Filipović rekao je da bi taj proces trajao i do mjesec i pol ako bi se poštovale sve razine raspravljanja - analitičko-komunikacijsko tijelo (sastavljeno od tajnika organa upravljanja, predsjednika Centralnoga radničkog savjeta, člana Poslovodnoga odbora, predstavnika Saveza komunista i sindikata i predsjednika konferencija delegata), konferenciju općih delegacija, radničkih savjeta OOUR-a i radnih zajednica pa do zborova radnih ljudi - stoga su se često pojedine razine preskakale, najčešće nauštrb „običnih” radnika. ${ }^{40}$

U manjim je organizacijama informiranje bilo lakše, međutim čak i u organizacijama koje su se bavile kulturnim radom, poput primjerice Gradske glazbe općine Pula, komunikacija delegata s bazom često je bila svedena na informiranje o radu, a manje na raspravu i usklađivanje stavova koje će delegat zastupati. ${ }^{41}$ Nadalje, na redovitim sastancima radnih organizacija pitanje kulture teško je moglo doći na red: primjerice, Bruno Gambin, šef poslovnice

37 „Program aktivnosti u izradi i zaključivanju samoupravnih sporazuma o slobodnoj razmjeni rada za 1977. godinu”, Bilten RSIZK, 6 (1976), 22.

38 „Djelovanje RSIZK u razdoblju 1975. do 1979.”, Bilten RSIZK, 24 (1979), 21.

39 „Analiza stanja informiranja interesnih zajednica u oblasti kulture udruženih RSIZK za 1979.”, Bilten RSIZK, 28 (1980), 58. Usp. „Plan RSIZK za razdoblje od 1981. do 1985.”, Bilten RSIZK, 35 (1982), 10.

40 D. NEŽIĆ, „Skupština SIZ-a - tribina OUR-a davalaca usluga”, Kulturni vjesnik, 31 (1984), 21.

41 Miroslav SINČIĆ, „Delegat još uvijek nemoćan”, Kulturni vjesnik, 26 (1982), 3-4. 
tekstila u Šijani te predsjednik Skupštine SIZ-a kulture općine Pula, primijetio je da se u radnoj organizaciji radnici fokusiraju na tekuće probleme i stjecanje dohotka, pa su ostale teme, uključujući i kulturu, često bivale zaobiđenima ili površno dotaknutima. ${ }^{42}$

Stoga se čak i uz najbolju volju pojedinih delegata njihova pozicija često svodila

„na izoliranog pojedinca, koji se sam borio s hrpama materijala, s terminima održavanja sjednica, s argumentima da se određene odluke moraju donijeti jer će u protivnom biti zaustavljen rad pojedinih kulturnih djelatnosti, pa nije čudo što se u brojnim slučajevima pretvorio u pasivnog glasača za prijedlog izvršnih organa skupštine, odnosno stručne službe". ${ }^{43}$

Zbog svega toga postojao je opravdan strah da delegati često glasaju za određene odluke bez ovlasti i konzultacija sa svojom sredinom, vodeći se vlastitim nahođenjem, stavovima i potrebama ili jednostavno prihvaćajući servirani materijal. ${ }^{44}$ Ivan Škrinjarić, glavni direktor Arene - modne trikotaže Pula, bio je ipak skloniji blažoj kritici delegatskoga sustava, napominjući da je potrebno vrijeme da se radnik-samoupravljač obrazuje i navikne na aktivno sudjelovanje u donošenju odluka: „Od nas se traži da znamo sve o materijalnoj proizvodnji, o kulturi, o školstvu, zdravstvu, socijalnoj zaštiti i svemu ostalome što je u nadležnosti SIZ-ova, a činjenica je da nam samoupravna svijest još nije na tom nivou." ${ }^{45}$ Po njegovu mišljenju, trebale su proći barem tri generacije radnika-samoupravljača da bi se sustav napokon uhodao te da bi se riješili ostataka budžetsko-fondovskoga razmišljanja o kulturi.

„Staro” shvaćanje o odlučivanju kao problem nefunkcionalnosti delegatskoga sustava u SIZ-ovima kulture detektirao je i Miroslav Sinčić, koji se 1982. u Kulturnom vjesniku još uvijek bavio pitanjem delegata „jer se osnovne koncepcije i stavovi utvrđuju prethodno u općinskim organima društveno-političkih organizacija, u općinskim izvršnim vijećima, općinskim skupštinama (bez četvrtog vijeća!), raznim komitetima, koordinacijama i sl.”, svodeći iznošenje stavova delegata i glasanje na puku formalnost. ${ }^{46}$ Napominje da je $u$ SIZ-u kulture čest stav da

„ni do kakvih izmjena više ne dolazi, niti može doći, jer su 'materijali’ već upućeni ili su čak 'prošli' javnu raspravu, i kako sada da dođe do promjena, tko i kako da ponovo pokrene mašineriju samoupravnog odlučivanja! Objašnjenja zašto se stav neke delegacije ne može uvažiti uglavnom se svode na to da je to stav samo jedne delegacije, da nema smisla zato pokretati novu javnu raspravu, osim toga to ne bi bilo u skladu s 'dogovorenim opredjeljenjima',

${ }_{42}$ O. VIŠKOVIĆ, „Kulturne aktivnosti u zapećku”, Kulturni vjesnik, 18 (1979), 2-4.

43 ĐOKIĆ, Samoupravni preobražaj kulture, 32.

44 SR-AJ-463-SKPZJ, kut. 7, Sednica Sekretarijata ZKPOJ, 20. 7. 1977.

45 Daniel NAČINOVIĆ, Olga VIŠKOVIĆ, „Stabilizacija u kulturi”, Kulturni vjesnik, 19 (1979), 7-8.

46 Miroslav SINČIĆ, „Delegat još uvijek nemoćan”, Kulturni vjesnik, 26 (1982), 3-4. 
ne možemo mi, drugovi, za svaku 'sitnicu' pred udruženi rad, vidjet ćemo to na našem Predsjedništvu, pa ako Predsjedništvo bude smatralo... Takve se rasprave vode obično pred kraj sjednice Skupštine, delegatima je svega već dosta, kasno je već, svima se žuri, neki moraju na posao u smjenu, drugi u vrtić po dijete, treći na neki novi sastanak... Dajte, ljudi da glasamo pa da idemo...!"'47

I delegati iz vijeća davalaca usluga primjećivali su strukturne probleme u funkcioniranju delegatskoga sustava, pogotovo one koji su se odnosili na nepoštovanje demokratskih procedura i načela jednakosti među delegatima iz dvaju vijeća. Vojni umirovljenik Darko Pavićević, delegat Gradske glazbe u vijeću davalaca usluga, naglašavao je klanovske podjele u Skupštini, kao i verbalno „iživljavanje” „profesionalnih diskusanata”; knjižničarka Marija Petener-Lorencin, delegatkinja Naučne biblioteke, smatrala je da Skupština više sliči debatnom klubu nego delegatskoj skupštini, zamjerajući najvećim dijelom Predsjedništvu što često nije uvažavalo mišljenja i prijedloge delegata; na manjak demokracije i nemogućnost sukreiranja programa i suodlučivanja upozorila je i profesorica Meri Dragičević, delegatkinja Saveza kulturno-umjetničkih društava. ${ }^{48}$

Taj problem nije bio specifičnost općine Pula. Istraživanje Republičkoga SIZ-a kulture 1979. utvrdilo je da je samo 30,7 posto predstavnika SIZ-ova kulture smatralo da su materijali potpuno prilagođeni za uspješno odlučivanje određene zajednice. Posebno je bila zabrinjavajuća spoznaja da samo 10,6 posto predstavnika upućuje alternativne prijedloge pojedinih odluka na prethodnu raspravu, što je zapravo značilo da se delegatsko glasanje zaista svodilo na formalnost potvrđivanja odluka koje su prethodno donijeli kulturni radnici ili Predsjedništvo SIZ-a. ${ }^{49}$

Zbog svih tih faktora sjednice SIZ-a kulture općine Pula, pogotovo one na kojima su se donosili godišnji i srednjoročni programi i financijski planovi, odrađivale su samo formalne zahtjeve samoupravnoga preobražaja kulture. Iako detaljni zapisnici sa sjednica nisu sačuvani - a i upitno je koliko su i sami zapisnici sadržavali detalje s rasprava, a koliko su tek donosili zaključke po točkama dnevnoga reda - iz analiziranoga materijala objavljivanog u Kulturnom vjesniku očito je da se i u programiranju i u financiranju kulturnih aktivnosti malo toga mijenjalo u petnaestogodišnjem razdoblju postojanja SIZ-a kulture općine Pula. Uvidom u samoupravne sporazume o kulturnim djelatnostima, programu rada i slobodnoj razmjeni rada u oblasti kulture koji su se potpisivali svake godine može se zaključiti da je stopa koju su radnici izdvajali iz svojega dohotka bila zacementirana od 1976. te se nije znatnije mijenjala tijekom godina s razvojem samoupravljanja u kulturi. Tako članak 3. Samoupravnoga sporazuma iz 1976. određuje plaćanje doprinosa po stopi od 0,52

47 Isto.

48 Isto.

49 „Analiza stanja informiranja interesnih zajednica u oblasti kulture udruženih RSIZK za 1979.", Bilten RSIZK, 28 (1980), 55. 
posto na bruto osobne dohotke, a člankom 12. Sporazuma iz 1978. detaljnije su razrađene stope doprinosa, i to kako slijedi: doprinos iz osobnoga dohotka radnika u udruženom radu po stopi od 0,60 posto, doprinos iz osobnoga dohotka od samostalnoga obavljanja poljoprivrednih djelatnosti po stopi od 0,20 posto, doprinos iz osobnoga dohotka radnika od samostalnoga obavljanja privrednih i neprivrednih djelatnosti po stopi od 1 posto te doprinos iz osobnoga dohotka radnika za zadovoljavanje zajedničkih potreba na razini republike po stopi od 0,12 posto. ${ }^{50}$ Doprinosi su se znatnije mijenjali jedino s porastom gospodarske krize sredinom 80 -ih, međutim čak se i to odnosilo na kratkotrajna mjesečna razdoblja rebalansa proračuna, pa je primjerice od listopada do prosinca 1984. stopa doprinosa smanjena sa 0,52 na 0,25 posto, a već u siječnju 1985. vratila se na stari iznos. ${ }^{51}$

U usporedbi s podatkom iz 1978. koji donosi Đokić, općina Pula bila je prosječna u svojim izdvajanjima za kulturu ako se uzme u obzir da je najniža stopa izdvajanja u nekim općinama iznosila tek 0,10 posto, a najviša 1,10 posto, pri čemu su općine s većim brojem kulturnih institucija odredile više stope..$^{52} \mathrm{U}$ tom kontekstu, kao općina koja možda nije spadala u sam vrh, ali definitivno jest u višu kategoriju po mogućnosti izdvajanja za kulturu, ipak se postavlja pitanje jesu li iznosi koji su se izdvajali za funkcioniranje i razvoj kulture u općini Pula bili dostatni. Za konačan odgovor bit će ipak nužno provesti daljnja i komparativna istraživanja na razini SRH.

„Stabilnost” iznosa stope osobnoga dohotka koji se izdvajao za razvoj kulture mogla bi se protumačiti kao dokaz stabilnosti kulturne politike. Međutim, uzimajući u obzir mnogobrojna neriješena infrastrukturna pitanja u općini (primjerice kazališna zgrada) ili izjednačavanje osobnoga dohotka radnika u kulturi s dohotkom ostalih radnika, koje do kraja proučavanoga razdoblja nije ostvareno, oboje pitanja za koja u ovom radu zbog opsega teme nije bilo mjesta, prije bi se mogla shvatiti kroz prizmu sporoga i neefikasnoga preobražaja kulture. U prilog tome osim problema s kojima se suočavao delegatski sustav govori i to da se stopa od 0,52 posto gotovo uopće nije mijenjala tijekom proučavanoga razdoblja. ${ }^{53}$

\footnotetext{
50 „Samoupravni sporazum o kulturnim djelatnostima, programu rada i slobodnoj razmjeni rada u oblasti kulture za 1976.”, Kulturni vjesnik, 9 (1976); „Obrazloženje uz financijski plan za 1978.”, Kulturni vjesnik, 13 (1978), 17; HR-HDA-1605-RSIZK, kut. 2, Izvršni odbor Skupštine RSIZK, Stenografski zapisnik XI sjednice IO Skupštine RSIZK (20. 2. 1976.).

51 D. N., „U skladu sa financijskim mogućnostima”, Kulturni vjesnik, 33 (1984), 13.

52 ĐOKIĆ, Samoupravni preobražaj kulture, 30.

53 „Izvodi iz izvještaja o radu SIZK za razdoblje od srpnja 1979. do veljače 1982.”, Kulturni vjesnik, 26 (1982), 13-15.
} 


\section{Zaključak}

Prikazana praksa funkcioniranja SIZ-a kulture općine Pula i njegova delegatskoga sustava pokazuje nemogućnost ostvarivanja samoupravnoga preobražaja kulture dokle god se on bazirao na automatskom glasanju na već pripremljene odluke koje je daleko od očiju baze - radnika u OUR-ima i građana u mjesnim zajednicama - pripremao netko drugi, bili to radnici u kulturi ili stručne službe SIZ-a kulture. Najveći dio OUR-a materijalne proizvodnje nije doživio kulturnu transformaciju, a velik dio njih nije imao ni razrađene planove potreba koje je trebalo ostvariti, kao ni nekoga unutar samoga sustava tko je mogao djelovati kao stručna osoba, tj. animator kulture unutar samoga OUR-a. Zbog toga se najveći dio kulturnih aktivnosti odvijao u razvijanju vlastitih inicijativa, odnosno amaterskim kulturnim samoaktivnostima pojedinih radnika. Ni oni radnici koji su bili uključeni u procese odlučivanja - delegati - s jedne strane nisu imali podršku svojih radnih organizacija za izgradnju kvalitetnoga foruma za raspravu o kulturi unutar OUR-a, a s druge strane nisu imali priliku ostvariti se kao ravnopravni partneri u raspravama na sjednicama SIZ-a kulture.

$\mathrm{Na}$ drugom kraju spektra, radnici u OUR-ima kulture i drugi kulturni radnici velikim su dijelom zadržali elitistički pogled na kulturu te nisu u dovoljnoj mjeri bili spremni na kompromise koje su nosili pokušaji demokratizacije i samoupravnoga preobražaja kulture. Iako su u teoriji bili nadvladani budžetski i fondovski načini financiranja kulture, prikazano funkcioniranje potpisivanja samoupravnih sporazuma više je sličilo odnosu trgovca i kupca nego jednakih partnera koji zajedno nešto stvaraju. Međutim, u neuspjehu ostvarenja sustava kako je bio zamišljen ispaštali su i oni jer izdaci iz osobnih dohodaka koje je sve radno stanovništvo općine izdvajalo nisu bili dostatni za dostojne dohotke radnika u kulturi, pa je onda i pitanje o dostizanju dohotka radnika u kulturi onoga ostalih radnika postajalo sve češće s porastom gospodarske krize 80 -ih godina.

No valja naglasiti da su stanoviti pomaci ipak postojali. Ako ništa drugo, na temeljnoj razini pitanje kulture u svakodnevnom životu radnika ipak se otvorilo u javnosti. Kulturni vjesnik iz broja u broj donosi i mnoge pozitivne priče iz OUR-a materijalne proizvodnje i mjesnih zajednica. Iako su to često bili prikazi amaterskih kulturno-umjetničkih djelatnosti, bilo to bavljenje likovnim radom, pisanje poezije ili njegovanje tradicijskih plesova i kulture, radnici su ipak dobili poticaj za samoostvarenje.

Nadalje, za razliku od prijašnjih načina financiranja i programiranja kulture, preko uspostavljenoga delegatskog sustava ipak su osnovne informacije mogle doći do krajnjih korisnika (a i financijera), što je svakako bio korak prema demokratizaciji kulture. Ako ništa drugo, delegatski sustav ispunjavao je barem ono fundamentalno načelo demokracije, a to je da je svaki radnik mogao biti biran delegatom te se kroz svoj rad u SIZ-u kulture obrazovati i dugoročno primijeniti svoje znanje na svoju radnu zajednicu. Konačno, zbog 
konstantne kritičnosti koja je dolazila iz redova Kulturnoga vjesnika, ali i iz izvještaja s rasprava viših instanci u republičkom i federalnom sustavu, SIZ-ovi kulture, uključujući i onaj pulski, stalno su bili motivirani da iznova iznalaze nova rješenja za probleme koji su se pojavljivali pri uspostavljanju i funkcioniranju delegatskoga sustava. ${ }^{54}$ Vraćajući se na spomenutu misao Ivana Škrinjarića, može se samo spekulirati bi li se samoupravni preobražaj kulture ostvarivanjem odnosa slobodne razmjene rada i uz pomoć delegatskoga sustava zaista ostvario za tri generacije radnika. Eksperiment je iznenada prekinut 1990., a raspadom države nestali su i modeli koje je socijalistička vlast uspostavila.

Tek će daljnja istraživanja koja ovaj rad otvara, odgovarajući na primjenu i praksu pitanja i teorijskih razmatranja iz prvoga dijela rada, moći dati odgovor o uspješnosti samoupravnoga preobražaja kulture u socijalističkoj Hrvatskoj. Ta će istraživanja svakako morati uključiti komparativne analize nekoliko mikrolokacija, kao i druge aspekte samoupravljanja u kulturi, sve da bi kulturna povijest socijalističke Hrvatske kasnijega razdoblja dobila prostor koji u historiografiji zaslužuje.

\section{Arhivski i neobjavljeni izvori}

HR-HDA-1605-RSIZK: Hrvatska, Hrvatski državni arhiv, Zagreb, fond 1605, Republička samoupravna interesna zajednica kulture.

SR-AJ-320-SKNK: Srbija, Arhiv Jugoslavije, Beograd, fond 320, Savezni komitet za nauku i kulturu.

SR-AJ-463-SKPZJ: Srbija, Arhiv Jugoslavije, Beograd, fond 463, Savez kulturno-prosvetnih zajednica Jugoslavije.

\section{Objavljeni izvori i tisak}

Bilten Republičke samoupravne interesne zajednice kulture (Zagreb), 19761982.

Kulturni vjesnik (Pula), 1974-1988.

\section{Literatura}

DIMIĆ, Ljubodrag. Agitprop kultura: agitpropovska faza kulturne politike u Srbiji 1945-1952. Beograd: Rad, 1988.

DIMITRIJEVIĆ, Branislav. Potrošeni socijalizam. Kultura, konzumerizam i društvena imaginacija u Jugoslaviji (1950-1974). Beograd: Fabrika knjiga; Peščanik, 2016.

DOKNIĆ, Branka. Kulturna politika Jugoslavije 1946-1963. Beograd: Službeni glasnik, 2013.

ĐOKIĆ, Ljupče. Samoupravni preobražaj kulture. Zagreb: Sindikalna škola Hrvatske „Josip Cazi”, 1984.

${ }_{54}$ Olga V. MANDIĆ, „Racionalizacija”, Kulturni vjesnik, 42 (1988), 2. 
GRBAC, Željko. Kultura na društvenoj pozornici. Zagreb: Školska knjiga, 1987.

KAUZLARIĆ, Vesna. „Kulturne djelatnosti u organizacijama udruženog rada”. Informatica Museologica 8 (1977), br. 3-4: 53-57.

MAJER, Boris. Kultura između države i tržišta. Beograd: SSRNJ, 1970.

MAJSTOROVIĆ, Stevan. Kultura i demokratija. Beograd: Prosveta, 1978.

MARTINIĆ, Tena. Kultura kao samoodređenje. Zagreb: Cekade, 1986.

NAJBAR-AGIČIĆ, Magdalena. Kultura, znanost, ideologija. Prilozi istraživanju politike komunističkih vlasti u Hrvatskoj od 1945. do 1960. na polju kulture i znanosti. Zagreb: Matica hrvatska, 2013.

NIKOLIĆ, Kosta; CVETKOVIĆ, Srđan; TRIPKOVIĆ, Đoko. Bela knjiga - 1984. Obračun sa „kulturnom kontrarevolucijom” u SFRJ. Beograd: Službeni glasnik; ISI, 2010.

PRNJAT, Branko. Kulturna politika i kulturni razvoj. Beograd: Radnička štampa, 1979.

RANKOVIĆ, Milan. Kultura i nekultura. Beograd: „Vuk Karadžić”, 1974.

ROLANDI, Francesca. Con ventiquattromila baci. L'influenza della cultura di massa italiana in Jugoslavia (1955-1965). Bologna: Bononia University Press, 2015.

SENJKOVIĆ, Reana. Izgubljeno u prijenosu: pop iskustvo soc kulture. Zagreb: Institut za etnologiju i folkloristiku, 2008.

SPASKOVSKA, Ljubica. The Last Yugoslav Generation: The Rethinking of Youth Politics and Cultures in Late Socialism. Manchester: Manchester University Press, 2017.

ŠUVAR, Stipe. Kulturna politika i idejna borba. Beograd: Borba, 1983.

ŠUVAR, Stipe. Politika i kultura. Zagreb: Globus, 1980.

ŠUVAR, Stipe. Svijet obmana. Zagreb: „August Cesarec”, 1986.

VUČETIĆ, Radina. Koka-kola socijalizam. Amerikanizacija jugoslovenske popularne kulture šezdesetih godina XX veka. Beograd: Službeni glasnik, 2012.

VUČETIĆ, Radina. Monopol na istinu. Partija, kultura i cenzura u Srbiji šezdesetih i sedamdesetih godina XX veka. Beograd: Clio, 2016.

ZUBAK, Marko. The Yugoslav Youth Press (1968-1980): Student Movements, Youth Subcultures and Alternative Communist Media. Zagreb: Srednja Europa, 2018. 


\section{SUMMARY}

\section{Self-Managing Transformation of Culture through the Prism of Delegates: The Example of the Pula Self-Managing Community of Interest 1974-1990}

Self-managing transformation of culture as a concept gained importance after numerous political and social changes in the Socialist Federal Republic of Yugoslavia (SFRY), such as the adoption of a new Constitution in 1974 and the introduction of the Associated Labour Law in 1976. The term itself covers everything from party politics and workers' (amateur) cultural practices, through free exchange of labour, to issues such as the humanisation of labour, interpersonal relations, and culture as a way of life. The proclaimed further democratisation of culture was to be achieved through the establishment of free exchange of labour between cultural workers (service providers) and workers in joint labour organisations (organizacije udruženog rada, OURs) and citizens in the local communities (mjesne zajednice, MZs), which was supposed to take place in the OURs and self-managing communities of interest (samoupravne interesne zajednice, SIZs). Through the establishment of bicameral delegate councils (one chamber comprising the 'users', i.e. the delegates of material production OURs and local communities, and the other 'providers', i.e. the delegates of culture OURs, amateur cultural-artistic associations, and independent artists), the cultural SIZs on the municipal level had to secure the conditions for satisfying the special and general cultural needs of all inhabitants of the municipality. This paper analyses the success of cultural reform on the micro level on the example of the Pula municipality, with special focus on the functioning of the delegate system.

Key words: cultural policy; socialism, self-management; Pula; self-managing community of interest 